\title{
Methodology for the Structuring of the Negotiation of Biotechnology Products with Intangible Assets Associated
}

\author{
Dora García Delgado* and Maritza Ortíz Torres \\ Center for Genetic Engineering and Biotechnology Havana, Havana University, Cuba
}

Submission: April 24, 2017; Published: May 04, 2017

"Corresponding author: Dora García Delgado, Center for Genetic Engineering and Biotechnology Havana, Havana University, Cuba, Email: dora.garcia@heber-biotec.co

\section{Mini Review}

From the whole universe of intangibles assets generated in the biotechnology industry it was designed a Methodology for the Valuation and Negotiation of the following intangible assets: Research and development project in early stage of its development, trademarks, technologies and patents, taking as start point the sequence of the negotiation preparation shown in Figure 1 but focusing in the valuation and negotiation of the intangible asset. The stages to follow up are the following:

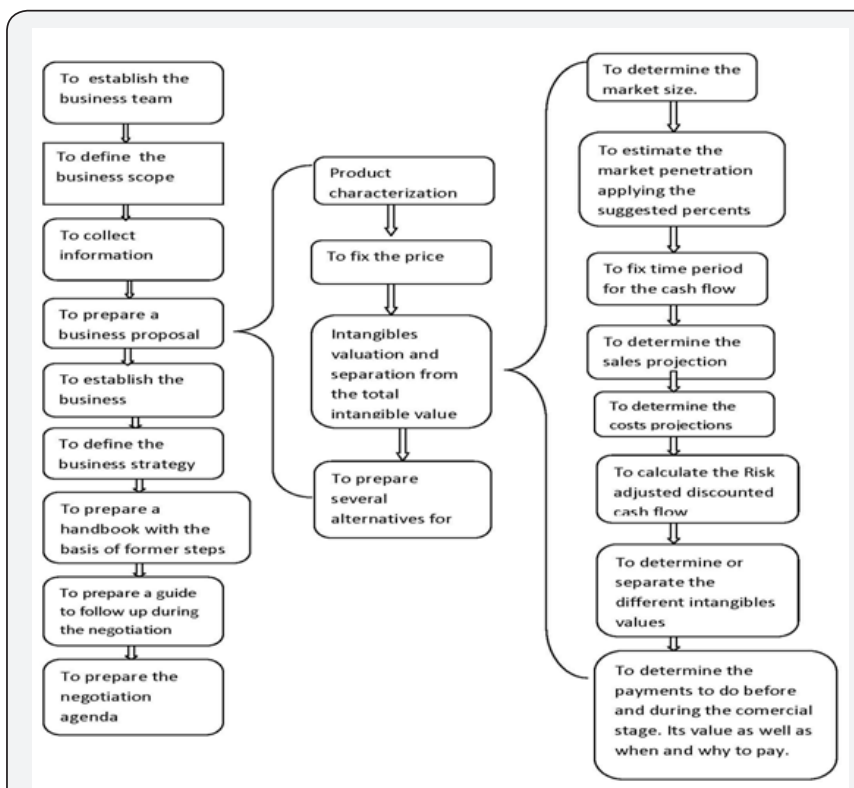

Figure 1: Methodology for the valuation and negotiation of biotechnology products with intangibles.

In the methodology each step of the sequence shown is explained and a theoretical fundament or a result of the observance is given. In the intangible valuation the way to calculate each element is detailed.

To fix the price of a novel product with patent the sales cost is not considered but it's proposed how to calculate the price of biotechnology products in three typical cases:
I. A novel product indicated for a health problem for which there is no alternative drugs, a unique product, it's proposed to take as reference the cost of the present treatment (there is no drug, but a surgery or other therapy is used) adjusting such value in dependence of the strengths and weakness of the new product. It's suggested to negotiate this price on the base of the advantages of a phamacoeconomy study. On the base of the practical experience in this case a market penetration between $10 \%$ and $15 \%$ is proposed to calculate the market size

II. When a product is a novel one but there are others products in the market indicated for the same health problem but the new one is more effective and may be consider a new generation of the drug, on the base of the patent strength and the advantages concerning the other products in the market, the price may be higher than the price of the other products, then an strategy canvas [1] is recommended in order to know the pricing position of the novel concerning the other products and in spite of the advantage an adjustment in the

price should be done during negotiation if necessary, but never drop the price at the competitors level. On the base of the practical experience in this case a market penetration between $5 \%$ and $10 \%$ is proposed to calculate the market size

III. Biosimilars, in which case the reference for fix the price is the patent product's price but biosimilar price should be fixed under patent product price. On the base of the practical experience in this case a market penetration between $1 \%$ and $5 \%$ is proposed to calculate the market size Considering that a patent guaranty a novel result protection during 20 years, that a novel result is patented in the early stages of its development and that a product development takes around 10 years, 10 years is the time period proposed to consider to make the cash flow of the early stage project. 
To calculate the net present value (NPV) the discount rate applied is $15 \%$ for novel products and for advanced stages of development projects and $18 \%$ for early stages projects. Once the traditional NPV is calculated the risk in the clinical development is considered discounting from NPV a risk percent in order to obtain the VAN adjust to clinical risk (rNPV).

To separate the intangible value from the rNPV in the case of a patent and a project in advance stage of development it's proposed to combine the risk adjusted discounted cash flow and the technological factor methods. To separate the intangible value of a trademark, Inter brand method is applied. The result from the application of the proposed methods combination in different cases was a range from $6 \%$ to $12 \%$ for the factor to be applied to the rNPV in order to separate the mentioned intangibles value in a biotechnology product.

Once the intangible value is separated in the methodology the ranges and values of the payment to perform before and during the commercial stages are proposed, this ranges and values are the same published by the author in Applied Biotechnology journal [2].

\section{References}

1. Chan Kim, Renée Mauborgne (2008) Blue Ocean Strategy. Harvard Business School Press, Nueva York, USA, ISBN 9788492421282.

2. García Delgado Dora (2014) On the negotiation of biotechnology products that include intangibles assets. Applied Biotechnology 31(4): 1027-2852.

\section{Your next submission with Juniper Publishers will reach you the below assets}

- Quality Editorial service

- Swift Peer Review

- Reprints availability

- E-prints Service

- Manuscript Podcast for convenient understanding

- Global attainment for your research

- Manuscript accessibility in different formats

( Pdf, E-pub, Full Text, Audio)

- Unceasing customer service

Track the below URL for one-step submission https://juniperpublishers.com/online-submission.php 